\title{
Kinetics of soil enzyme activities under different ecosystems: An index of soil quality
}

\author{
Monty Kujur ${ }^{1}$, and Amiya KumarPatel ${ }^{2 *}$
}

Soil microbial activity plays an important role in regulating biotransformation, nutrient cycling and hence the microbiological processes are at the center of many ecological functions. The kinetic parameters $\left(\mathrm{V}_{\max }\right.$ and $\mathrm{K}_{\mathrm{m}} \mathrm{Michaelis}$ constant) of different enzymes (amylase, invertase, protease, urease, and dehydrogenase) were determined in order to assess the metabolic response of soil. The maximum reaction velocity $\left(\mathrm{V}_{\max }\right)$ represents a maximum rate of activity when all enzymes are saturated, which markedly increased in forest soil as compared to fresh mine spoil due to the gradual accumulation of soil organic matter. Smaller $\mathrm{K}_{\mathrm{m}}$ value was estimated in forest soil (FS) as compared to fresh mine spoil (FMS), suggesting the greater affinity of soil enzymes for substrate in FS. The catalytic efficiency $\left(V_{\max } / K_{m}\right)$ reflects an impression on microbial community composition with a change in soil enzymes. These enzyme characters (activities and kinetic parameters) have greater significance as early and sensitive indicators of the changes in soil properties induced by different management systems. These parameters $\left(\mathrm{V}_{\max }\right.$ and $\left.\mathrm{K}_{\mathrm{m}}\right)$ can be useful markers to assess changes in microbial activity of soil, since they represent quantity and affinity of enzymes respectively. The metabolic index (dehydrogenase activity/organic carbon (OC)) was found to be correlated with $\mathrm{V}_{\max }$ of dehydrogenase $(\mathrm{r}=0.953 ; p<0.01)$ and $\mathrm{OC}(\mathrm{r}=$ $0.880 ; p<0.01)$. Principal component analysis was able to discriminate seven different soil samples into seven independent clusters based on their enzyme activities and kinetic parameters. Indeed, the study revealed the importance of kinetics study of soil enzymes, which can be considered valid parameters to monitor the evolution of microbiological activity in soil, and hence an index of soil quality.

Key words: Amylase, invertase, protease, urease, dehydrogenase.

\section{INTRODUCTION}

Microbes in soil play a pivotal role by producing various enzymes (Zhang et al., 2009), which are constantly being synthesized, accumulated, inactivated and/or decomposed in soil (Tabatabai, 1994; Dick et al., 1994). Soil enzymes contribute to the total biological activities, because they are intimately involved in catalyzing reactions necessary for the stabilization of soil structure, organic matter $(\mathrm{OM})$ decomposition and dissolved $\mathrm{OM}$ production (Allison and Vitousek, 2005), mineralization, and nutrient cycling (Tabatabai, 1994; Dick et al., 1994), energy transfer and environmental quality. Soil enzymatic activities are a useful tool for assessing the functional diversity of soil microbial communities or organic mass turnover (Kandeler et al., 1999). The activities of these enzymes in soils undergo complex biochemical processes consisting of integrated and ecologically connected synthetic processes. Soil nutrient correlate to soil productivity, while soil enzymatic characteristics can provide information about the status of key biochemical reactions involved in

${ }^{1}$ Sambalpur University, School of Life Sciences, At/po-Jyoti Vihar, Burla; Dist-Sambalpur, Pin-768019, Odisha, India.

*Corresponding author (amiya_gene@yahoomail.com).

Received: 6 July 2013.

Accepted: 12 December 2013.

doi: $10.4067 /$ S0718-58392014000100015 rate limiting steps of biotransformation of soil nutrients.

Enzyme activities may have the potential to be used as indicators of soil quality, sustainability and changes in biogeochemical function due to management or perturbations. In general, soil enzyme activities can be used to characterize abundance and metabolic activity of soil microbes, where as kinetic parameters are used to describe catalytic activity, origin, and substrate affinity of the enzymes (Zhang et al., 2009). Soil enzyme activity provides an indication of its amount and its overall contribution in soil (Farrell et al., 1994), while enzyme kinetics study can provide useful information regarding their origin, existing status and catalytic properties, state and behavior of soil enzymes.

Kinetic parameters $\left(\mathrm{V}_{\max }\right.$ and $\left.\mathrm{K}_{\mathrm{m}}\right)$ are often used to characterize free enzymes in solution, they are considered to be constant for a specific enzyme under defined experimental conditions (Marx et al., 2005), but they may vary independently. Maximum reaction velocity $\left(\mathrm{V}_{\max }\right)$ of an enzyme catalyzed reaction imply splitting velocity or rate of dispersion of enzyme-substrate complex into enzyme and reaction products, which reflects the conjunction affinity between enzyme and substrate. The higher or lower $\mathrm{V}_{\max }$ value can be used as an indicator to speedy or slow enzymatic process. $\mathrm{V}_{\max }$ and $\mathrm{K}_{\mathrm{m}}$ of an enzyme express the quantity of an enzyme and substrate affinity, respectively (Marx et al., 2005; Davidson et al., 
2006). However, Michaelis constant $\left(\mathrm{K}_{\mathrm{m}}\right)$ represents the endurance of an enzyme-substrate complex, which is related with the substrate. The efficiency of the enzymes to decompose substrate at low concentration is directly related to their $\mathrm{K}_{\mathrm{m}}$ value (Marx et al., 2005; Davidson et al., 2006). Higher is the endurance of an enzyme-substrate complex, lower will be the $\mathrm{K}_{\mathrm{m}}$ value. Enzymes catalyzing the same reaction, but derived from different sources of soil have different $K_{m}$ values (Nannipieri et al., 1990). Besides, $\mathrm{K}_{\mathrm{m}}$ is independent of enzyme concentration and kinetically reflects the apparent affinity of enzyme for the substrate. In other words, smaller the $\mathrm{K}_{\mathrm{m}}$ value, the greater will be the affinity for the substrate (Masciandaro et al., 2000). However, estimating $K_{m}$ is challenging due to the uncertainty regarding the relative contribution of artificial and naturally occurring substrate under nonsaturating conditions (Stone et al., 2011). Moreover, enzymes may operate under non-saturating conditions in soil, which supplements $\mathrm{K}_{\mathrm{m}}$ an important parameter that merits increased attention (Davidson et al., 2006; German et al., 2011). If substrate concentration is similar to $K_{m}$, the measure of affinity for substrate/enzyme can provide information about the adsorption level or enzyme accessibility. Besides, $\mathrm{K}_{\mathrm{m}}$ influences enzyme activity at low substrate concentration (Davidson and Janssens, 2006; Davidson et al., 2006). Many investigations have dealt with the kinetic properties of enzymes (Masciandaro et al., 2000; Zhang et al., 2009; 2010; Juan et al., 2010).

Further, the $V_{\max } / K_{m}$ value represents the formation of an enzyme-substrate complex and the comparison of dispersion of this complex in soil. Higher value of $\mathrm{V}_{\max } /$ $\mathrm{K}_{\mathrm{m}}$ suggests that dispersion of enzyme-substrate complex occurs faster than its formation (Ekberli et al., 2006; Kizilkaya et al., 2007). The catalytic efficiency of soil enzymes i.e. $\mathrm{V}_{\max } / \mathrm{K}_{\mathrm{m}}$ (Gianfreda et al., 1995) was highly affected by physico-chemical properties of soil (Dick et al., 1994), source of available substrate for the enzyme (Garcia et al., 1993; Kizilkaya and Bayrakli, 2005), soil OM content (Garcia et al., 1993), stimulation of microbial activity by compounds containing $\mathrm{N}, \mathrm{P}$, and $\mathrm{K}$, and the synthesis of enzymes by increasing microbial populations.

In the present study, five enzymes (amylase, invertase, protease, urease, and dehydrogenase) representative of important nutrient cycles were selected. Amylase, invertase, and protease are hydrolytic enzymes, which control the decomposition of various biological macromolecules abundant in plant litter and soil. Amylase is a starch hydrolyzing enzyme (Ross, 1983) widely distributed in soils that hydrolyzes starch mainly to form reducing sugar an energy source for soil microbes (Eivazi and Tabatabai, 1990) and small quantity of maltose. Invertase ( $\beta$-fructofuranosidase, E.C.: 3.2.1.5) hydrolyzes sucrose into glucose and fructose. The soil invertase activity is used as an index for nutrient transformation, energy metabolism, and pollutant degradation (Nannipieri et al., 1990). Soil proteases are extracellular enzymes produced mainly by bacteria, which degrade proteins and release $\mathrm{NH}_{4}-\mathrm{N}$ important in $\mathrm{N}$ cycle (Sardans et al., 2008). Estimation of proteases provides information on $\mathrm{N}$ mediated biochemical processes in soil (Sardans and Peñuelas, 2005) and play a significant role in $\mathrm{N}$ mineralization regulating the amount of plant available $\mathrm{N}$. Soil urease (E.C.: 3.5.1.5) is responsible for the breakdown of urea into $\mathrm{CO}_{2}$ and ammonia. Its origin is basically microbial and its activity is extracellular (Tabatabai, 1994; Dick et al., 1994; Kizilkaya et al., 2004). It acts as an intermediary enzyme in the transformation of organic $\mathrm{N}$ in soil. Information regarding the nature of urease activity is beneficial for developing and employing strategies for efficient N management (Ekberli et al., 2006; Kizilkaya et al., 2007; Kizilkaya and Ekberli, 2008). Urease activity is used as a soil quality indicator (Yang et al., 2006; Makoi and Ndakidemi, 2008). Dehydrogenase activity can be used as an index of overall microbial activity (Nannipieri et al., 1990; Tabatabai, 1994), and is linked with microbial respiratory processes, which can provide information about the key reactions involved in rate limiting steps of microbial oxidoreduction processes.

Soil enzyme activities are very sensitive to both natural and anthropogenic disturbances, and show a quick response to induced changes. The variation in soil enzyme activities is due to the variation in OM, microbial community, microbial activity associated with soil biological processes, which are affected by biotic and abiotic factors. Differential microbial community may produce distinct enzyme isoforms, which could differ in their catalytic properties and hence their $\mathrm{V}_{\max }$ and $\mathrm{K}_{\mathrm{m}}$. Therefore, the knowledge about soil enzyme activities, kinetic properties, and their variation has considerable biological significance, which paves the way of greater understanding the direction of improving soil fertility. Further, the kinetic parameter is most attractive from the standpoint of the forensic comparison of soil, since it is independent of sample size and its potential usefulness is thereby enhanced. Realizing this, an attempt was made in the study with an aim to provide a comparative account on the variations in the kinetic properties of different soil enzymes, and to illustrate if kinetics of soil enzyme activities can be used as indices for soil fertility.

\section{MATERIALS AND METHODS}

\section{Study site}

The present study was carried out in sponge iron mines in Noamundi $\left(22^{\circ} 9^{\prime} 49.96^{\prime \prime} \mathrm{N}, 8^{\circ} 30^{\prime} 33.61^{\prime \prime} \mathrm{E} ; 540 \mathrm{~m}\right.$ a.s.l.) maintained by Tata Iron Steel Corporation limited (TISCO), which is located in the revenue district of West Singhbhum, Jharkhand, India (Figure 1). The area is surrounded by a number of new, old and abandoned mines of iron ore overburden. Tropical dry deciduous forest is considered to be the natural vegetation of the area, but rapid development of transportation network and 


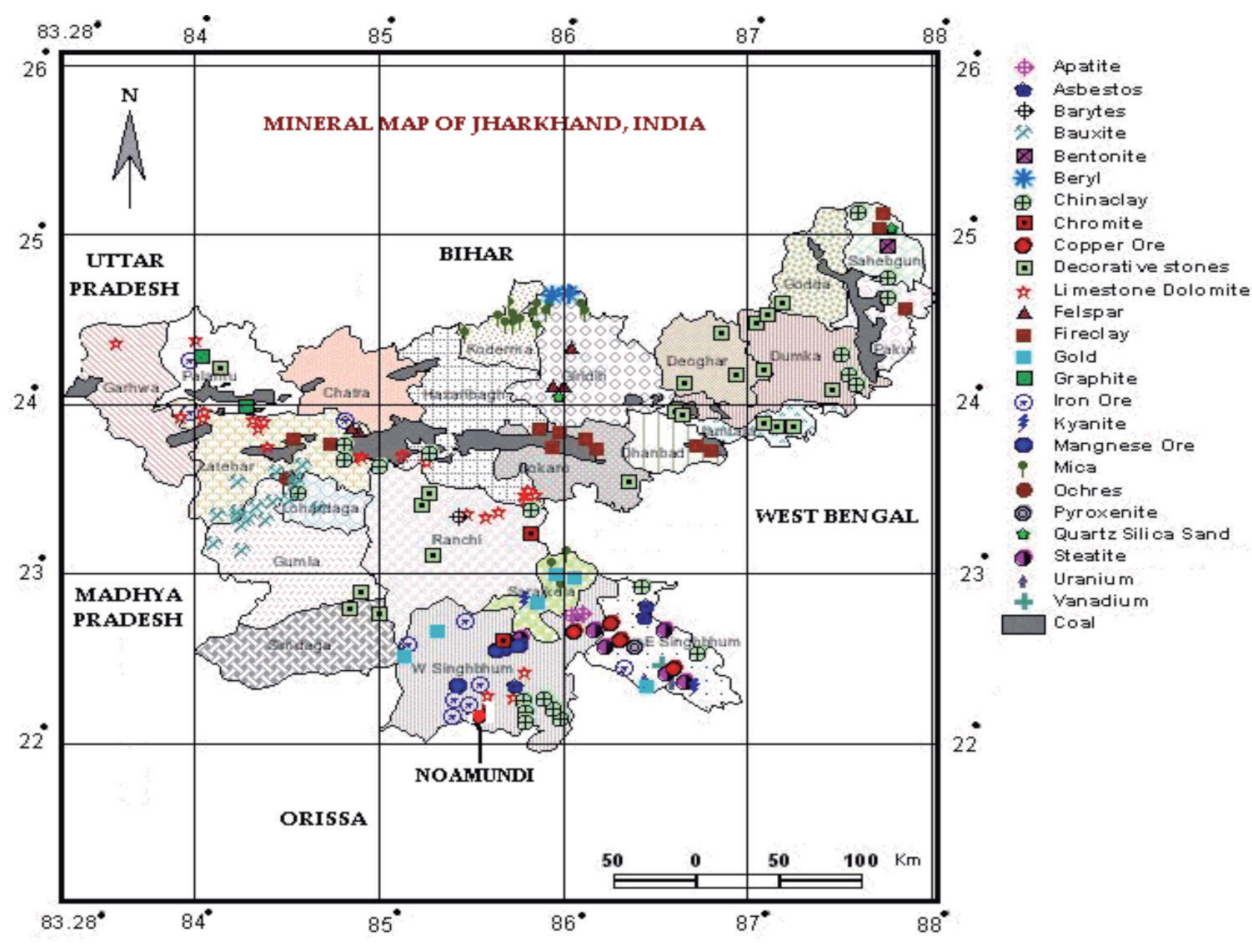

Figure 1. Geographical location and the mineral map of study site, Jharkhand, India.

industrialization led to the decline of forest cover mainly due to the felling and biotic interferences. Mean annual temperature and humidity is around $19.67{ }^{\circ} \mathrm{C}$ and $20 \%$ respectively.

\section{Soil sampling}

Sampling was done in accordance with the general method of soil microbiological study. Seven different sites: fresh mine spoil (FMS); 6 yr old mine spoil (MS); degraded waste land soil (DWS); grassland soil (GS); pesticidetreated soil (PTS); agricultural soil (AS) and forest soil (FS) were selected for sampling near Noamundi within $10 \mathrm{~km}$ peripheral distance from the mining area. Each site was divided into three blocks, and during each sampling five soil samples were collected randomly from $0-15 \mathrm{~cm}$ soil depth by digging pits of $15 \times 15 \times 15 \mathrm{~cm}$ size in each block. These samples collected from each block were referred to as 'sub-samples', which were brought to the laboratory in sterilized polythene packets and thoroughly mixed to form one 'composite sample'. Thus, during each sampling, three composite samples were obtained from each site. Similar strategy has been followed for soil sampling from different study sites in the month of August. The composite samples were subjected to sieving ( $2 \mathrm{~mm}$ mesh size) for characterization.

\section{Soil enzyme activities}

Amylase activity of different soil samples was determined in adaptation to the procedures described by Somogyi
(1952) and Roberge (1978) taking starch as substrate and incubating at $30{ }^{\circ} \mathrm{C}$ for $24 \mathrm{~h}$. Invertase activity was determined by spectrophotometric method (Ross, 1983) using sucrose as substrate and incubating at $37^{\circ} \mathrm{C}$ for 24 h. Protease activity was determined by spectrophotometric method (Ladd and Butler, 1972) with sodium caseinate as a substrate. Urease activity was determined by spectrophotometrically at $578 \mathrm{~nm}$ (Hoffmann and Teicher, 1961) using urea as substrate. Dehydrogenase activity was measured by the following reduction of 2,3,5-triphenylotetrazolium chloride (TTC) as an artificial electron acceptor to red-colored triphenyl formazon (TPF), which were determined spectrophotometrically (Nannipieri et al., 1990).

Kinetic parameters $\left(\mathrm{K}_{\mathrm{m}}\right.$ and $\left.\mathrm{V}_{\max }\right)$ of different soil enzyme activities were determined taking five different substrate concentrations individually. The substrate concentrations used for soil amylase, invertase, protease, urease, and dehydrogenase activities were ranged from 5 to $50 \mathrm{mM}, 10$ to $100 \mathrm{mM}, 1$ to $10 \mathrm{mM}, 5$ to $45 \mathrm{mM}$, and 10 to $90 \mathrm{mM}$, respectively. For every substrate concentration, triplicate analyses were carried out.

\section{Kinetic parameters determination}

The soil enzymes follow Michaelis Menten kinetics, despite soil being considered as a discontinuous, structured and heterogeneous system (Nannipieri et al., 2002). Michaelis-Menten equation linearized by LineweaverBurk was used to determine $\mathrm{V}_{\max }$ (maximal velocity), $\mathrm{K}_{\mathrm{m}}$ 
(substrate concentration at $1 / 2 \mathrm{~V}_{\max }$ ) by plotting a graph i.e. $1 / \mathrm{V}$ against $1 /$ [substrate concentration], and estimated by the intercept and slope respectively, and $\mathrm{V}_{\max } / \mathrm{K}_{\mathrm{m}}$ as kinetic parameters.

$$
\frac{1}{\mathrm{~V}}=\frac{\mathrm{K}_{\mathrm{m}}}{\mathrm{V}_{\max }} \cdot \frac{1}{[\mathrm{~S}]}+\frac{1}{\mathrm{~V}_{\max }}
$$

\section{Statistical analysis}

Data from soil analyses were subjected to simple correlation analysis to test the statistical significance of soil physico-chemical properties and soil enzyme activities between seven soil samples using SPSS Statistics 17.0 software. Principal components analysis (PCA) was performed using Statistix PC DOS Version-2.0 (NH Analytical Software).

\section{RESULTS AND DISCUSSION}

Soil enzymes are important for their role in nutrient cycling and were considered to be early indicators of specific biochemical reactions in soil, because of their relationship to soil biology, ease of measurement (Dick et al., 1994; Kizilkaya and Bayrakli, 2005), and rapid response to changes in soil managements (Kandeler et al., 1999; Zhang et al., 2010).

Kinetics study of soil amylase activity indicated an increasing trend in $\mathrm{V}_{\max }$ from FMS (4.3292 $\mu \mathrm{g} \mathrm{g}^{-1}$ soil $\left.\mathrm{h}^{-1}\right)$ to FS $\left(66.9231 \mu \mathrm{g} \mathrm{g}^{-1}\right.$ soil $\left.^{-1}\right)$. Higher $\mathrm{V}_{\max }$ value was estimated in AS as compared to PTS, but much lower in GS and DWS. The $\mathrm{V}_{\max }$ of soil amylase was higher in MS (11.7646 $\mu \mathrm{g} \mathrm{g}^{-1}$ soil h$^{-1}$ ) as compared to FMS (Table 1 ). Soil invertase can catalyze the rupture of $\beta$-glucose bonds resulting in sucrose hydrolysis into glucose and sucrose, and it is an important enzyme, which reflects the transformation mechanism of organic C. It not only reflects the biological properties of soil, but also serves as an evaluation indicator of soil maturity and fertility level. Comparisons of soil invertase activity showed similar trend, i.e. progressive increase in $\mathrm{V}_{\max }$ value from FMS (10.1563 $\mu \mathrm{g} \mathrm{g}^{-1}$ soil h$\left.^{-1}\right)$ to FS (1250.5132 $\mu \mathrm{g} \mathrm{g}^{-1}$ soil $\left.\mathrm{h}^{-1}\right)$. The MS (41.5135 $\mu \mathrm{g} \mathrm{g}^{-1}$ soil $\mathrm{h}^{-1}$ ) exhibited higher $\mathrm{V}_{\max }$ value as compared to FMS. Similarly, $\mathrm{V}_{\max }$ for soil invertase activity was higher in AS (787.6191 $\mu \mathrm{g} \mathrm{g}^{-1}$ soil $\mathrm{h}^{-1}$ ) as compared to PTS, GS, and DWS (Table 1).

It is evident from data that soil amylase activity and its $\mathrm{V}_{\max }$ value were positively correlated with WHC, MC, organic $\mathrm{C}$, total $\mathrm{N}$, and available $\mathrm{P}$, but negatively correlated with bulk density (Table 2). Similarly, the soil invertase activity and its $\mathrm{V}_{\max }$ value were also positively correlated with WHC, MC, organic C, total N, and available P, but negatively correlated with bulk density (Table 3). Such variation in soil amylase as well as invertase activity with

Table 1. Michaelis constant $\left(K_{m}\right)$ and maximum reaction velocity $\left(V_{\max }\right)\left(\mu \mathbf{g ~ g}^{-1}\right.$ soil $\left.^{-1}\right)$ of different soil enzymes.

\begin{tabular}{|c|c|c|c|c|c|c|c|c|}
\hline Soil enzymes & $\begin{array}{c}\text { Kinetic } \\
\text { parameters }\end{array}$ & FMS & MS & DWS & GS & PTS & AS & FS \\
\hline \multirow[t]{4}{*}{ Amylase } & $\mathrm{V}_{\max }$ & 4.3292 & 11.7646 & 31.2508 & 43.4785 & 52.5412 & 55.5555 & 66.9231 \\
\hline & $\mathrm{K}_{\mathrm{m}}(\mathrm{mM})$ & 47.109 & 35.474 & 29.515 & 17.384 & 14.217 & 13.115 & 11.108 \\
\hline & $\mathrm{V}_{\max } / \mathrm{K}_{\mathrm{m}}$ & 0.0918 & 0.3316 & 1.0588 & 2.5010 & 3.6956 & 4.2360 & 6.0247 \\
\hline & $R^{2}$ & $0.877^{*}$ & $0.861^{*}$ & $0.954^{* *}$ & $0.949^{* *}$ & $0.880^{* *}$ & $0.980^{* *}$ & $0.934^{* *}$ \\
\hline \multirow[t]{4}{*}{ Invertase } & $\mathrm{V}_{\max }$ & 10.1563 & 41.5135 & 229.5071 & 325.4267 & 742.8251 & 787.6191 & 1250.5132 \\
\hline & $\mathrm{K}_{\mathrm{m}}(\mathrm{mM})$ & 41.398 & 32.818 & 28.554 & 25.609 & 19.995 & 19.631 & 17.365 \\
\hline & $\mathrm{V}_{\max } / \mathrm{K}_{\mathrm{m}}$ & 0.2453 & 1.2649 & 8.0376 & 12.7075 & 37.1505 & 40.1211 & 72.0134 \\
\hline & $R^{2}$ & $0.737^{*}$ & $0.797^{*}$ & $0.877^{* *}$ & $0.892^{* *}$ & $0.938^{* *}$ & $0.839^{* *}$ & $0.871^{* *}$ \\
\hline \multirow[t]{4}{*}{ Protease } & $\mathrm{V}_{\max }$ & 5.6997 & 15.2765 & 52.1908 & 75.2672 & 142.8991 & 168.8752 & 320.0864 \\
\hline & $\mathrm{K}_{\mathrm{m}}(\mathrm{mM})$ & 22.157 & 18.013 & 13.116 & 12.083 & 11.985 & 11.651 & 10.183 \\
\hline & $\mathrm{V}_{\max } / \mathrm{K}_{\mathrm{m}}$ & 0.2572 & 0.8480 & 3.9791 & 6.2291 & 11.9231 & 14.4944 & 31.4334 \\
\hline & $R^{2}$ & $0.995^{* *}$ & $0.847^{* *}$ & $0.924^{* *}$ & $0.987^{* *}$ & $0.719^{*}$ & $0.774^{*}$ & $0.908^{* * *}$ \\
\hline \multirow[t]{4}{*}{ Urease } & $\mathrm{V}_{\max }$ & 10.1568 & 12.0484 & 27.0275 & 31.2518 & 33.3333 & 34.4823 & 37.0371 \\
\hline & $\mathrm{K}_{\mathrm{m}}(\mathrm{M})$ & 0.085 & 0.071 & 0.062 & 0.045 & 0.036 & 0.032 & 0.028 \\
\hline & $\mathrm{V}_{\max } / \mathrm{K}_{\mathrm{m}}$ & 119.4917 & 169.6957 & 435.9274 & 694.4844 & 925.9250 & 1077.5718 & 1322.7535 \\
\hline & $R^{2}$ & $0.921^{\text {** }}$ & $0.997^{* *}$ & $0.859^{* *}$ & $0.870^{* *}$ & $0.947^{* *}$ & $0.826^{* *}$ & $0.837^{* *}$ \\
\hline \multirow[t]{4}{*}{ Dehydrogenase } & $\mathrm{V}_{\max }$ & 0.8662 & 1.8772 & 3.2583 & 3.4002 & 4.3725 & 4.5614 & 5.6249 \\
\hline & $\mathrm{K}_{\mathrm{m}}(\mathrm{M})$ & 0.201 & 0.131 & 0.067 & 0.043 & 0.034 & 0.031 & 0.025 \\
\hline & $\mathrm{V}_{\max } / \mathrm{K}_{\mathrm{m}}$ & 4.3094 & 14.3297 & 48.6313 & 79.0744 & 128.6029 & 147.1419 & 224.9960 \\
\hline & $R^{2}$ & $0.976^{* * *}$ & $0.990^{* *}$ & $0.905^{* *}$ & $0.873^{* *}$ & $0.935^{* *}$ & $0.927^{* *}$ & $0.971^{* * *}$ \\
\hline
\end{tabular}

${ }^{* * *}$ Correlation is significant at $p<0.01$; ${ }^{*}$ correlation is significant at $\mathrm{p}<0.05$.

FMS: fresh mine spoil; MS: 6 yr old mine spoil; DWS: degraded waste land soil; GS: grassland soil; PTS: pesticide-treated soil; AS: agricultural soil; FS: forest soil; and $\mathrm{V}_{\max } / \mathrm{K}_{\mathrm{m}}$ : catalytic efficiency.

Table 2. Simple correlation between soil properties and amylase activity.

\begin{tabular}{|c|c|c|c|c|c|c|c|c|c|c|c|c|}
\hline Parameters & Clay & BD & WHC & $\mathrm{MC}$ & $\mathrm{pH}$ & $\mathrm{OC}$ & $\mathrm{TN}$ & $\mathrm{AP}$ & $\begin{array}{l}\text { Amylase } \\
\text { activity }\end{array}$ & $\mathrm{V}_{\max }$ & $\mathrm{K}_{\mathrm{m}}$ & $\mathrm{V}_{\max } / \mathrm{K}_{\mathrm{m}}$ \\
\hline Amylase activity & $0.969^{* * *}$ & $-0.956^{* * *}$ & $0.965^{* *}$ & $0.979^{* *}$ & $0.965^{* *}$ & $0.990^{* *}$ & $0.926^{* *}$ & $0.983^{* *}$ & 1 & & & \\
\hline $\mathrm{V}_{\max }$ & $0.983^{* *}$ & $-0.972^{* * *}$ & $0.976^{* *}$ & $0.955^{* *}$ & $0.975^{* *}$ & $0.980^{* *}$ & $0.911^{* *}$ & $0.982^{* *}$ & $0.990^{* * *}$ & 1 & & \\
\hline $\mathrm{K}_{\mathrm{m}}$ & $-0.974^{* *}$ & $0.998^{* *}$ & $-0.996^{* *}$ & $-0.928^{* *}$ & $-0.990^{* * *}$ & $-0.934^{* *}$ & $-0.827^{*}$ & $-0.928^{* *}$ & $0.963^{* *}$ & $-0.974^{* *}$ & 1 & \\
\hline $\mathrm{V}_{\max } / \mathrm{K}_{\mathrm{m}}$ & $0.937^{* *}$ & $-0.893^{* *}$ & $0.919^{* *}$ & $0.981^{* *}$ & $0.928^{* * *}$ & $0.992^{* *}$ & $0.974^{* *}$ & $0.979^{* *}$ & $0.983^{* *}$ & $0.962^{* *}$ & $-0.906^{* *}$ & 1 \\
\hline
\end{tabular}

${ }^{* * *}$ Correlation is significant at $p<0.01 ;{ }^{*}$ correlation is significant $p<0.05$ (2-tailed test).

BD: Bulk density; WHC: water holding capacity; MC: moisture content; OC: organic C; TN: total N; AP: available P; $\mathrm{V}_{\text {max }}$ : maximum reaction velocity; $\mathrm{K}_{\mathrm{m}}$ : Michaelis constant; and $\mathrm{V}_{\max } / \mathrm{K}_{\mathrm{m}}$ : catalytic efficiency. 
Table 3. Simple correlation between soil properties and invertase activity.

\begin{tabular}{|c|c|c|c|c|c|c|c|c|c|c|c|c|}
\hline Parameters & Clay & $\mathrm{BD}$ & WHC & $\mathrm{MC}$ & $\mathrm{pH}$ & $\mathrm{OC}$ & $\mathrm{TN}$ & AP & $\begin{array}{l}\text { Invertase } \\
\text { activity }\end{array}$ & $\mathrm{V}_{\max }$ & $\mathrm{K}_{\mathrm{m}}$ & $\mathrm{V}_{\max } / \mathrm{K}_{\mathrm{m}}$ \\
\hline Invertase activity & $0.885^{* *}$ & $-0.804^{*}$ & $0.846^{*}$ & $0.943^{* *}$ & $0.866^{*}$ & $0.960^{* * *}$ & $0.994^{* * *}$ & $0.950^{* *}$ & 1 & & & \\
\hline $\mathrm{V}_{\max }$ & $0.918^{* *}$ & $-0.844^{*}$ & $0.879^{* *}$ & $0.968^{* *}$ & $0.892^{* *}$ & $0.972^{* *}$ & $0.982^{* *}$ & $0.972^{* *}$ & $0.993^{* *}$ & 1 & & \\
\hline $\mathrm{K}_{\mathrm{m}}$ & $-0.994^{* *}$ & $0.984^{* *}$ & $-0.994^{* * *}$ & $-0.946^{* * *}$ & $-0.995^{* *}$ & $-0.944^{* * *}$ & $-0.860^{*}$ & $-0.950^{* *}$ & $-0.861^{*}$ & $-0.893^{* *}$ & 1 & \\
\hline $\mathrm{V}_{\max } / \mathrm{K}_{\mathrm{m}}$ & $0.875^{* *}$ & $-0.790^{*}$ & $0.833^{*}$ & $0.946^{* *}$ & $0.851^{*}$ & $0.948^{* *}$ & $0.985^{* *}$ & $0.943^{* *}$ & $0.995^{* * *}$ & $0.995^{* *}$ & $-0.850^{*}$ & 1 \\
\hline
\end{tabular}

${ }^{* * *}$ Correlation is significant $p<0.01 ;{ }^{*}$ correlation is significant $p<0.05$ (2-tailed test).

BD: Bulk density; WHC: water holding capacity; MC: moisture content; OC: organic C; TN: total N; AP: available P; $\mathrm{V}_{\text {max }}$ : maximum reaction velocity; $\mathrm{K}_{\mathrm{m}}$ : Michaelis constant; and $\mathrm{V}_{\max } / \mathrm{K}_{\mathrm{m}}$ : catalytic efficiency.

respect to seven different soil samples may be due to the variation in available soil nutrients (Kujur et al., 2012). The organic C content was significantly correlated with soil enzyme activities (Eivazi and Tabatabai, 1990; Kujur et al., 2012). Increased soil nutrients lead to increase in microbial biomass (Singh et al., 2007; Kujur and Patel, 2012) and diversity of soil micro-biota causes increased microbial enzyme production and hence higher $\mathrm{V}_{\max }$ (Allison and Martiny, 2008; Nemergut et al., 2008; Stone et al., 2011). The type of OM was shown to influence activities of amylase and invertase more than quantity of OM. The decrease in $\mathrm{V}_{\max }$ in FMS is attributable mainly to the declination of enzyme synthesis due to the accumulation of heavy metals and associated toxic effects on soil microbes. The heavy metals may cause changes in the active center and structure of soil enzymes, thus making the soil amylase as well as invertase concentration decrease and inhibit the decomposition of starch and sucrose respectively. Besides, the interaction of heavy metals inhibits the microbial growth (Yang et al., 2006; Gao et al., 2009), thus reducing the synthesis, secretion of enzymes and finally leading to the decrease in soil amylase and invertase activity (He et al., 2002). Besides, the increase in soil amylase and invertase activity in AS as compared to PTS can be explained due to the pesticide induced changes in the soil enzymes (Achuba, 2006) as well as in microbial community composition.

The $\mathrm{K}_{\mathrm{m}}$ value of soil amylase exhibited highest $\mathrm{K}_{\mathrm{m}}$ value (i.e. $47.109 \mathrm{mM}$ ) in FMS, and then decreased with increasing soil moisture content (Kujur and Patel, 2012). The $\mathrm{K}_{\mathrm{m}}$ value estimated in FS was minimal i.e. 11.108 $\mathrm{mM}$ (Table 1). Similar trend was also exhibited in soil invertase activity, where $K_{m}$ value ranges from 41.398 $\mathrm{mM}$ (FMS) to $17.365 \mathrm{mM}$ (FS) (Table 1). The $\mathrm{K}_{\mathrm{m}}$ value of soil amylase and invertase activity showed negative correlation with all the tested soil properties except bulk density (Tables 2 and 3). The substrate diffusion rate affects $K_{m}$ value due to the typical heterogenic system of soil. The stronger enzyme-substrate affinity (lower $\mathrm{K}_{\mathrm{m}}$ value) in higher moisture content may be caused by the higher diffusion rate because of more water solubility (Zhang et al., 2009). Soil amylase $K_{m}$ value as well as invertase of AS and PTS were much smaller than those in GS, DWS, MS, which may be due to the fact that AS and PTS contain much more OM and medium textured soil (Kujur and Patel, 2012) exhibit better soil structure that protect the enzyme active site, resulting lower $K_{m}$ value. Secondly, the potential reason of lower $K_{m}$ in FS as compared to other soils may be due to the higher water availability (water holding capacity) because of higher OM content (Zhang et al., 2009). Further, $\mathrm{V}_{\max } / \mathrm{K}_{\mathrm{m}}$ value of soil amylase was estimated to be lowest in FMS (0.0918) as compared to FS (6.0247) (Table 1). Similar trend was also exhibited in soil invertase i.e. minimal in FMS (0.2453) and maximum in FS (72.0134) (Table 1). The lowest value of $\mathrm{V}_{\max } / \mathrm{K}_{\mathrm{m}}$ in FMS may be attributed to the extreme soil dryness that limits solubility and restrict movement of the available organic $\mathrm{C}$ as energy source and thus limits the microbial respiration.

The protease activity depends upon the amount of proteinaceous substrate available in the soil OM as well as on the distribution of proteolytic bacteria. The increase in $\mathrm{V}_{\max }$ value of soil protease showed a range from 5.6997 to $320.0864 \mu \mathrm{g} \mathrm{g}^{-1}$ soil $\mathrm{h}^{-1}$ with minimum in FMS and maximum in FS (Table 1). The $\mathrm{K}_{\mathrm{m}}$ value of soil protease varied from $22.157 \mathrm{mM}$ (FMS) to $10.183 \mathrm{mM}$ (FS), and $\mathrm{V}_{\max } / \mathrm{K}_{\mathrm{m}}$ value ranged from 0.2572 (FMS) to 31.4334 (FS) (Table 1). The variation in soil protease activity between seven different soils was contributed by OC, TN, and AP (Kujur and Patel, 2012). The soil protease activity and its $\mathrm{V}_{\max }$ value exhibited positive correlation with different soil properties such as WHC, MC, $\mathrm{pH}, \mathrm{OC}, \mathrm{TN}$, and AP (except for $\mathrm{BD}$ ), whereas its $\mathrm{K}_{\mathrm{m}}$ value showed negative correlation with all the tested soil properties except BD (Table 4). The vegetation and the associated difference in litter inputs and root exudation in FS as compared to FMS may have contributed to increased $\mathrm{V}_{\max }$ value (Stone et al., 2011). Higher $\mathrm{V}_{\max }$ in AS (168.8752 $\mu \mathrm{g} \mathrm{g}^{-1}$ soil $^{-1}$ ) as compared to GS and DWS is due to the progressive improvement in organic $\mathrm{C}$ and $\mathrm{NH}_{4}-\mathrm{N}$ accumulation (Sardans and Peñuelas, 2005; Tischer, 2005) and the distribution of proteolyitc bacteria (Sardans et al., 2008; Anjaneyulu et al., 2011; Subrahmanyam et al., 2011). Higher $\mathrm{V}_{\max }$ in GS $\left(75.2672 \mu \mathrm{g} \mathrm{g}^{-1}\right.$ soil h $\left.\mathrm{h}^{-1}\right)$ is exhibited as compared to DWS (52.1908 $\mu \mathrm{g} \mathrm{g}^{-1}$ soil h$\left.^{-1}\right)$, which may be attributed to the gradual accumulation of proteinaceous substrate facilitated by the vegetation cover in course of time. Further, the gradual $\mathrm{N}$ accumulation stimulates the soil microbes for enhanced production of C-degrading enzymes.

Urease is mostly an extracellular enzyme representing up to $63 \%$ of total activity in soil. It belongs to soil hydrolases involved in urea hydrolysis (hydrolysis of soil amide $\mathrm{N}$ ) into $\mathrm{CO}_{2}$ and $\mathrm{NH}_{3}$, and consequently $\mathrm{N}$ losses 
Table 4. Simple correlation between soil properties and protease activity.

\begin{tabular}{|c|c|c|c|c|c|c|c|c|c|c|c|c|}
\hline Parameters & Clay & $\mathrm{BD}$ & WHC & $\mathrm{MC}$ & $\mathrm{pH}$ & $\mathrm{OC}$ & $\mathrm{TN}$ & $\mathrm{AP}$ & $\begin{array}{l}\text { Protease } \\
\text { activity }\end{array}$ & $\mathrm{V}_{\max }$ & $\mathrm{K}_{\mathrm{m}}$ & $\mathrm{V}_{\max } / \mathrm{K}_{\mathrm{m}}$ \\
\hline Protease activity & $0.779^{*}$ & -0.703 & $0.755^{*}$ & $0.861^{*}$ & $0.777^{*}$ & $0.886^{* *}$ & $0.981^{* *}$ & $0.864^{*}$ & 1 & & & \\
\hline $\mathrm{V}_{\max }$ & $0.863^{*}$ & $-0.786^{*}$ & $0.830^{*}$ & $0.925^{* *}$ & $0.849^{*}$ & $0.943^{* *}$ & $0.996^{* *}$ & $0.932^{* *}$ & $0.986^{* *}$ & 1 & & \\
\hline $\mathrm{K}_{\mathrm{m}}$ & $-0.938^{* *}$ & $0.963^{* *}$ & $-0.955^{* *}$ & $-0.826^{*}$ & $-0.949^{* *}$ & $-0.866^{*}$ & $-0.777^{*}$ & $-0.877^{\text {*** }}$ & -0.672 & -0.745 & 1 & \\
\hline $\mathrm{V}_{\max } / \mathrm{K}_{\mathrm{m}}$ & $0.825^{*}$ & -0.745 & $0.794^{*}$ & $0.897^{* *}$ & $0.815^{*}$ & $0.918^{* *}$ & $0.992^{* *}$ & $0.903^{* *}$ & $0.996^{* *}$ & $0.997^{* * *}$ & -0.710 & 1 \\
\hline
\end{tabular}

${ }^{* *}$ Correlation is significant $p<0.01$; "correlation is significant $p<0.05$ (2-tailed test).

BD: Bulk density; WHC: water holding capacity; MC: moisture content; OC: organic C; TN: total N; AP: available P; $\mathrm{V}_{\text {max }}$ : maximum reaction velocity; $\mathrm{K}_{\mathrm{m}}$ : Michaelis constant; and $\mathrm{V}_{\max } / \mathrm{K}_{\mathrm{m}}$ : catalytic efficiency.

by $\mathrm{NH}_{3}$ volatilization. Hence, emphasis on urease activity has been given in order to evaluate $\mathrm{N}$ supply to plants, because large $\mathrm{N}$ losses to atmosphere by volatilization mediated by these enzymes. Comparisons of $\mathrm{V}_{\max }$ of urease activity showed similar trend like protease activity i.e. progressive increase from $10.1568 \mu \mathrm{g} \mathrm{g}^{-1}$ soil $\mathrm{h}^{-1}$ (FMS) to $37.0371 \mu \mathrm{g} \mathrm{g}^{-1}$ soil h$^{-1}$ (FS) (Table 1). Similarly, the $\mathrm{V}_{\max }$ was found to be higher in MS (12.0484 $\mu \mathrm{g} \mathrm{g}^{-1}$ soil $\mathrm{h}^{-1}$ ) as compared to FMS, which represents nutrient deficient situation with altered geomorphic system (Kujur and Patel, 2012). Factors contributing higher $\mathrm{V}_{\max }$ in MS as compared to FMS may include the absence of disturbing, which mitigate the problem of runoff of the residual soil nutrients, and may due to the gradual establishment of vegetation cover in course time due to soil reclamation process. However, lower $\mathrm{V}_{\max }$ value of soil urease was estimated in PTS (33.3333 $\mu \mathrm{g} \mathrm{g}^{-1}$ soil h $\left.\mathrm{h}^{-1}\right)$ as compared to AS (34.4823 $\mu \mathrm{g} \mathrm{g}^{-1}$ soil $\left.\mathrm{h}^{-1}\right)$, due to the toxic effect of pesticides on soil microbes (Jayamadhuri and Rangaswamy, 2005). Further, less variation in $\mathrm{V}_{\max }$ between AS and PTS was due to the buffering effects of higher OM and clay percentage (Zhang et al., 2009).

The $\mathrm{K}_{\mathrm{m}}$ value soil urease activity varied from 0.085 $\mathrm{M}$ (FMS) to $0.028 \mathrm{M}$ (FS) (Table 1). PTS (0.036 M) exhibited higher $\mathrm{K}_{\mathrm{m}}$ as compared to AS $(0.032 \mathrm{M})$, which may be attributed to the formation of organo-urease complex, thereby decreasing the affinity of urease to its specific substrate urea or the conformational changes in the enzyme making its active sites less accessibility to its substrate (Juan et al., 2010). The greater differences in $\mathrm{K}_{\mathrm{m}}$ value between different soils suggested that the binding status and the origin of soil urease are dissimilar. Further, the seven different soil types undergo different pedogenic process resulted variation in physico-chemical properties and thus, soils are unlikely to have similar urease origin. The $\mathrm{V}_{\max } / \mathrm{K}_{\mathrm{m}}$ value in FMS (119.4917) was estimated to be lowest than FS (1322.7535). Furthermore, AS (1077.5718) exhibited higher $\mathrm{V}_{\max } / \mathrm{K}_{\mathrm{m}}$ value as compared to PTS, GS, and DWS (Table 1), which is due to the crop rotations with high input and diversity of OM containing higher concentrations of microbial biomass and enzyme activities (Klose and Tabatabai, 2000). Such variation in catalytic efficiency $\left(\mathrm{V}_{\max } / \mathrm{K}_{\mathrm{m}}\right)$ of soil urease (Gianfreda et al., 1995) may be due to variation in soil OM and soil texture (Garcia et al., 1993).

The variances in kinetic parameters of urease as a result of an increase in $\mathrm{V}_{\max }, \mathrm{K}_{\mathrm{m}}$ and $\mathrm{V}_{\max } / \mathrm{K}_{\mathrm{m}}$ due to the variation in physico-chemical properties of soil (Dick et al., 1994; Sarkar et al., 2003), moisture content (Sardans and Peñuelas, 2005; Kujur et al., 2012), OM and gradual accumulation of $\mathrm{N}$, which is considered to be the substrate for soil urease (Garcia et al., 1993; Kizilkaya and Bayrakli, 2005; Kizilkaya and Ekberli, 2008), and synthesis of urease enzyme by increasing microbial population. Urease activity shows a positive correlation with $\mathrm{N}$ availability, which indicated that this enzyme can be used to make some inferences about the nitrification process in soil and determine if $\mathrm{N}$ loses are due to volatilization, nitrification, or denitrification. Urease has been widely used for soil quality assessment, since its activity increases with organic fertilization and decreases with soil tillage (Saviozzi et al., 2001). Urease activity is influenced by microbial community, physicochemical properties of soil (Corstanje et al., 2007), OM, soil depth, heavy metals, temperature, and $\mathrm{pH}$ (Yang et al., 2006). Further, its stability is affected by organo-mineral complexes and humic substances (Makoi and Ndakidemi, 2008).

The soil urease activity exhibited positive correlation with $\mathrm{MC}$, organic $\mathrm{C}$, total $\mathrm{N}$ and available $\mathrm{P}$ (except for clay percentage, WHC, and $\mathrm{pH}$ ). Soil urease $\mathrm{V}_{\max }$ was positively correlated with all soil properties, except for bulk density. The $\mathrm{K}_{\mathrm{m}}$ values of soil urease had no significant correlation with urease activity, which suggested that $\mathrm{K}_{\mathrm{m}}$ is independent of enzyme concentration (Masciandaro et al., 2000). Further, it is evident from data that $\mathrm{V}_{\max } / \mathrm{K}_{\mathrm{m}}$ value, i.e. the catalytic efficiency of soil urease between the seven different soil samples, exhibited positive correlation with all the tested soil properties except $\mathrm{K}_{\mathrm{m}}$ and bulk density, which were negatively correlated (Table 5).

Estimation of dehydrogenase activity is attractive due to the fact that they are an integral part of soil microorganisms and are involved in OM oxidation. Dehydrogenase is involved electron transport system of oxygen metabolism and requires an intracellular environment (viable cells) to express its activity (Kandeler and Dick, 2007). Dehydrogenase enzyme is not present in extracellular form as hydrolases (urease, phosphatase), and hence it cannot be used to evaluate the process of soil degradation. The highest $\mathrm{V}_{\max }$ value was observed in FS (4.6249 $\mu \mathrm{g} \mathrm{g}^{-1}$ soil $\left.^{-1}\right)$ as compared to FMS $(0.8662$ $\mu \mathrm{g} \mathrm{g}^{-1}$ soil $^{-1}$ ) (Table 1). This is due to higher OM content in FS that support increased microbial activity 
Table 5. Simple correlation between soil properties and urease activity.

\begin{tabular}{|c|c|c|c|c|c|c|c|c|c|c|c|c|}
\hline Parameters & Clay & $\mathrm{BD}$ & WHC & $\mathrm{MC}$ & $\mathrm{pH}$ & $\mathrm{OC}$ & $\mathrm{TN}$ & $\mathrm{AP}$ & $\begin{array}{c}\text { Urease } \\
\text { activity }\end{array}$ & $\mathrm{V}_{\max }$ & $\mathrm{K}_{\mathrm{m}}$ & $\mathrm{V}_{\max } / \mathrm{K}_{\mathrm{m}}$ \\
\hline Urease activity & 0.695 & -0.620 & 0.677 & $0.768^{*}$ & 0.701 & $0.802^{*}$ & $0.939^{* *}$ & $0.780^{*}$ & 1 & & & \\
\hline $\mathrm{V}_{\max }$ & $0.956^{* *}$ & $-0.967^{* *}$ & $0.951^{\text {*** }}$ & $0.878^{* *}$ & $0.943^{* *}$ & $0.925^{* *}$ & $0.823^{*}$ & $0.940^{* *}$ & $0.946^{* * *}$ & 1 & & \\
\hline $\mathrm{K}_{\mathrm{m}}$ & $-0.987^{* *}$ & $0.988^{* *}$ & $-0.993^{* *}$ & $-0.965^{* *}$ & $-0.992^{* *}$ & $-0.969^{* *}$ & $-0.876^{* *}$ & $-0.963^{* *}$ & -0.692 & $-0.956^{* * *}$ & 1 & \\
\hline $\mathrm{V}_{\max } / \mathrm{K}_{\mathrm{m}}$ & $0.964^{* *}$ & $-0.929^{* *}$ & $0.945^{* *}$ & $0.980^{* *}$ & $0.951^{* *}$ & $0.999^{* *}$ & $0.954^{* *}$ & $0.993^{* *}$ & $0.804^{*}$ & $0.931^{* * *}$ & $-0.970^{* *}$ & 1 \\
\hline
\end{tabular}

${ }^{* *}$ Correlation is significant $p<0.01$; ${ }^{*}$ correlation is significant $p<0.05$ (2-tailed test).

BD: Bulk density; WHC: water holding capacity; MC: moisture content; OC: organic C; TN: total N; AP: available P; $\mathrm{V}_{\text {max }}$ : maximum reaction velocity; $\mathrm{K}_{\mathrm{m}}$ : Michaelis constant; and $\mathrm{V}_{\max } / \mathrm{K}_{\mathrm{m}}$ : catalytic efficiency.

and microbial biomass, consequently the concentration of soil dehydrogenase. Besides, less variation in $\mathrm{V}_{\max }$ was exhibited between AS and PTS, which may be due to the toxic effect of pesticides on soil microbes in PTS (Jayamadhuri and Rangaswamy, 2005). Further, the $\mathrm{V}_{\max }$ value in AS was found to be higher as compared to GS and DWS (Table 1). The $\mathrm{K}_{\mathrm{m}}$ value of soil dehydrogenase ranged from 0.201 M(FMS) to $0.025 \mathrm{M}$ (FS). The variation in $\mathrm{K}_{\mathrm{m}}$ value with respect to different soils can be explained on the basis of the capability of the enzyme catalyzing the same reaction can have different sources in soil and thus different $K_{m}$ values (Nannipieri et al., 1990). Value of $\mathrm{K}_{\mathrm{m}}$ reflects the apparent affinity of the enzyme for the substrate: the smaller the $K_{m}$ value, the greater the affinity ((Masciandaro et al., 2000). The catalytic efficiency ( $\mathrm{V}_{\max } /$ $\mathrm{K}_{\mathrm{m}}$ ) of soil dehydrogenase was found to be maximum in FS (224.996) and minimum in FMS (4.3094), which may be due to the change in the composition of soil microbiota with a change in the community of dehydrogenase (Masciandaro et al., 2000). Therefore, $\mathrm{V}_{\max }$ and $\mathrm{K}_{\mathrm{m}}$ of dehydrogenase act as useful markers to assess changes in microbial activity of soil, since they represented quality and affinity of dehydrogenase, respectively.

Several investigations have revealed correlations of soil dehydrogenase activity with soil respiration, ATP concentration, $\mathrm{C}$ and $\mathrm{N}$ turnover, OM content (Nannipieri et al., 1990). The soil dehydrogenase activity is positively correlated with all tested soil properties except bulk density, with which it had no correlation (Table 6). The $\mathrm{V}_{\max }$ value of soil dehydrogenase is positively correlated with all the variables, whereas it is negatively correlated with bulk density. However, the $\mathrm{K}_{\mathrm{m}}$ value of soil dehydrogenase showed negative correlation with all the tested soil properties except BD with which it is positively correlated. Similarly, catalytic efficiency of soil dehydrogenase was found to be positively correlated with the entire variables except BD (Table 6).
The kinetic parameters $\left(\mathrm{V}_{\max }\right.$ and $\left.\mathrm{K}_{\mathrm{m}}\right)$ of soil dehydrogenase activity were estimated in order to assess the metabolic response of a soil. The metabolic index is defined as the ratio between soil dehydrogenase activities and water soluble organic $\mathrm{C}$, has been suggested to represent the metabolic activity of soil (Masciandaro et al., 2000). The positive correlation between metabolic index (dehydrogenase activity/organic $\mathrm{C}$ ) and $\mathrm{V}_{\max }$ of soil dehydrogenase $(\mathrm{r}=0.953 ; p<0.01)$, and the organic $\mathrm{C}(\mathrm{r}$ $=0.880 ; p<0.01)$ indicated the ecological implications related to changes in different soil profiles with respect to their soil metabolic activity need to be considered. It is evident from data that changes in kinetic parameters of dehydrogenase activity seem to indicate a change in composition and activity of soil microbes. Thus, the metabolic potential index and kinetic constants of soil dehydrogenase may be used to monitor soil fertility.

Further, in order to view differences among seven different soils, principle component analysis (Ludwig and Reynolds, 1988) was performed to discriminate different sites on the basis of soil enzyme activity including enzyme kinetic parameters $\left(\mathrm{V}_{\max }, \mathrm{K}_{\mathrm{m}}\right.$, and $\left.\mathrm{V}_{\max } / \mathrm{K}_{\mathrm{m}}\right)$. The principal component analysis indicated that components $\mathrm{Z} 1$ and $\mathrm{Z} 2$ explained the maximum variance and their cumulative percentage of variance was $99 \%$, and well segregated seven different soils (Figure 2). Thus, the study clearly revealed that soil enzyme activity and kinetic parameters can serve as an integrative measure of soil quality.

\section{CONCLUSIONS}

The study suggested that forest soil (FS) support increased microbial activity and biomass due to higher organic matter content, and consequently exhibited higher maximum reaction velocity $\left(\mathrm{V}_{\max }\right)$ as compared to fresh mine spoil (FMS). Besides, lower $\mathrm{K}_{\mathrm{m}}$ value in FS as compared to other soil types explained the strong

Table 6. Simple correlation between soil properties and dehydrogenase (DH-ase) activity.

\begin{tabular}{|c|c|c|c|c|c|c|c|c|c|c|c|c|c|}
\hline Parameters & Clay & $\mathrm{BD}$ & WHC & MC & $\mathrm{pH}$ & $\mathrm{OC}$ & $\mathrm{TN}$ & $\mathrm{AP}$ & $\begin{array}{l}\text { DH-ase } \\
\text { activity }\end{array}$ & $\mathrm{V}_{\max }$ & $\mathrm{K}_{\mathrm{m}}$ & $\mathrm{V}_{\max } / \mathrm{K}_{\mathrm{m}}$ & $\begin{array}{c}\text { DH-ase } \\
\text { /OC }\end{array}$ \\
\hline DH-ase activity & $0.780^{*}$ & -0.700 & $0.755^{*}$ & $0.851^{*}$ & $0.782^{*}$ & $0.887^{* *}$ & $0.983^{* *}$ & $0.861^{*}$ & 1 & & & & \\
\hline $\mathrm{V}_{\max }$ & $0.985^{* *}$ & $-0.953^{* *}$ & $0.968^{* *}$ & $0.946^{* *}$ & $0.974^{* *}$ & $0.968^{* *}$ & $0.924^{* *}$ & $0.977^{* *}$ & $0.849^{*}$ & 1 & & & \\
\hline $\mathrm{K}_{\mathrm{m}}$ & $-0.946^{* *}$ & $0.977^{* *}$ & $-0.966^{* *}$ & $-0.835^{*}$ & $-0.957^{* *}$ & $-0.861^{*}$ & -0.748 & $-0.872^{*}$ & -0.639 & $-0.935^{* *}$ & 1 & & \\
\hline $\mathrm{V}_{\max } / \mathrm{K}_{\mathrm{m}}$ & $0.928^{* *}$ & $-0.870^{*}$ & $0.901^{* *}$ & $0.969^{* * *}$ & $0.914^{* *}$ & $0.984^{* *}$ & $0.988^{* *}$ & $0.976^{* *}$ & $0.945^{* *}$ & $0.954^{* *}$ & $-0.801^{*}$ & 1 & \\
\hline $\mathrm{DH}$-ase/OC & 0.686 & -0.676 & 0.725 & 0.583 & 0.756 & $0.880^{* * *}$ & 0.614 & 0.543 & $0.953^{* *}$ & 0.690 & -0.728 & 0.560 & 1 \\
\hline
\end{tabular}

${ }^{* *}$ Correlation is significant $p<0.01$; ${ }^{*}$ correlation is significant $p<0.05$ (2-tailed test).

BD: bulk density; WHC: water holding capacity; MC: moisture content; OC: organic C; TN: total N; AP: available P; $\mathrm{V}_{\text {max }}$ maximum reaction velocity; $\mathrm{K}_{\mathrm{m}}$ : Michaelis constant; and $\mathrm{V}_{\max } / \mathrm{K}_{\mathrm{m}}$ : catalytic efficiency. 


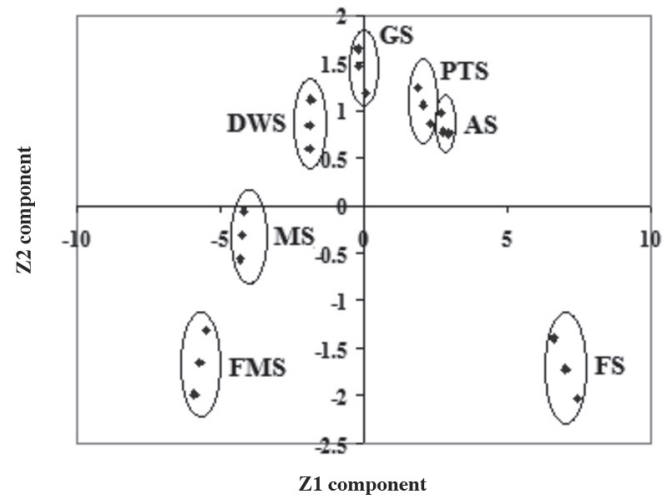

FMS: Fresh mine spoil; MS: 6 yr old mine spoil; DWS: degraded waste land soil; GS: grassland soil; PTS: pesticide-treated soil; AS: agricultural soil, and FS: forest soil.

Figure 2. Principal component analysis for different soil properties including enzyme activities and kinetic parameters of different soils (FMS, MS, DWS, GS, PTS, AS, and FS).

enzyme-substrate affinity of different soil enzymes in FS. Further, higher value of catalytic efficiency $\left(\mathrm{V}_{\max } / \mathrm{K}_{\mathrm{m}}\right)$ was exhibited by FS indicating higher rate of dispersion of enzyme-substrate complex as compared to FMS. The changes in the kinetic parameters of soil enzyme activities seem to indicate a change in composition and activity of soil microbiota, which can serve as an integrative measure of soil quality. Comparative assessment of the kinetic parameters $\left(\mathrm{V}_{\max }, \mathrm{K}_{\mathrm{m}}\right.$, and $\left.\mathrm{V}_{\max } / \mathrm{K}_{\mathrm{m}}\right)$ can able to discriminate seven different soil types and hence can be used as an index of soil quality and sustainability. The results obtained form the studies are of sufficient significance that is presumably extendable for soil quality assessment and management practices.

\section{ACKNOWLEDGEMENTS}

The authors are thankful to the Head of School of Life Sciences, Sambalpur University, Odisha, India, for providing the necessary laboratory facilities. The investigation was made possible through the financial support provided by the University Grant Commission (UGC), Government of India in terms of Rajiv Gandhi National Fellowship (RGNF) scheme.

\section{LITERATURE CITED}

Achuba, F.I. 2006. The effect of sub lethal concentrations of crude oil on the growth and metabolism of cowpea (Vigna unguiculata) seedlings. Environmentalist 26:17-20.

Allison, S., and J. Martiny. 2008. Resistance, resilience, and redundancy in microbial communities. Proceedings of National Academy of Sciences of the United States of America 105:1151211519.

Allison, S., and P. Vitousek. 2005. Responses of extracellular enzymes to simple and complex nutrient inputs. Soil Biology and Biochemistry 37:937-944.
Anjaneyulu, E., M. Balaji, G. Narasimha, and M. Ramgopal. 2011. Effect of pig iron slag particles on soil physico-chemical, biological and enzyme activities. Iranian Journal of Energy and Environment 2:161-165.

Corstanje, R., R. Schulin, and R. Lark. 2007. Scale-dependent relationships between soil organic matter and urease activity. European Journal of Soil Science 58:1087-1095.

Davidson, E.A., and I.A. Janssens. 2006. Temperature sensitivity of soil carbon decomposition and feedbacks to climate change. Nature 440:165-173.

Davidson, E.A., I.A. Janssens, and Y. Luo. 2006. On the variability of respiration in terrestrial ecosystems: moving beyond $\mathrm{Q}_{10}$. Global Change Biology 12:154-164.

Dick, R.P., J.A. Sandor, and N.S. Eash. 1994. Soil enzyme activities after 1500 years of terrace agricultural in the Colca valley. Peru. Agricultural Ecosystem Environment 50:123-131.

Eivazi, F., and M.A. Tabatabai. 1990. Factors affecting glucosidase and galactosidase activities in soils. Soil Biology and Biochemistry 22:891-897.

Ekberli, I., R. Kizilkaya, and N. Kars. 2006. Urease enzyme and its kinetic and thermodynamic parameters in clay loam soil. Asian Journal of Chemistry 18:3097-3105.

Farrell, R.E., V.V.S.R. Gupta, and J.J. Germida. 1994. Effect of cultivation of the activity and kinetics of arylsulfatase in Saskatchewan soils. Soil Biology and Biochemistry 26:10331040.

Gao, Y., P. Zhou, L. Mao, Y. Zhi, C. Zhang, and W. Shi. 2009. Effect of plant species coexistence on soil enzyme activities and soil microbial community structure under $\mathrm{Cd}$ and $\mathrm{Pb}$ combined pollution. Journal of Environmental Sciences 22:1040-1048.

Garcia, C., T. Hernández, F. Costa, B. Ceccenti, and G. Masciandaro. 1993. Kinetics of phosphatase activity in organic wastes. Soil Biology and Biochemistry 25:561-565.

German, D.P., S.S. Chacon, and S.D. Allison. 2011. Substrate concentration and enzyme allocation can affect rates of microbial decomposition. Ecology 92:1471-1480.

Gianfreda, L., A. Decristofaro, M.A. Rao, and A. Violante. 1995. Kinetic behavior of synthetic organo-and organo-mineral-urease complexes. Journal of Soil Science Society of America 59:811815.

He, W., M. Zhu, and Y. Zhang. 2002. Effects of mercury and cadmium on the activity of urease in soil. Chinese Journal of Applied Ecology 13:191-193.

Hoffmann, G.G., and K. Teicher. 1961. Ein kolorimetrisches Verfahren zur Bestimmung der UreaseAktivität in Böden. Zeitschrift Für Pflanzenernährung Düngung Bodenkunde 91:5563.

Jayamadhuri, R., and V. Rangaswamy. 2005. Influence of orghorous and carbamate insecticides on enzymatic activities of amylase, cellulase and invertase in two groundnut soil. Nature, Environment and Pollution Technology 4:385-393.

Juan, Y.H., L.J. Chen, Z.J. Wu, and R. Wang. 2010. Kinetics of soil urease affected by urease inhibitors at contrasting moisture regimes. Revista de la Ciencia del Suelo y Nutrición Vegetal/ Journal of Soil Science and Plant Nutrition 9:125-133.

Kandeler, E., and R. Dick. 2007. Soil enzymes: Spatial distribution and function in Agroecosystems. p. 263-279. In Benckiser, G., and S. Schnell (eds.) Biodiversity in agricultural production systems. CRC Press, Boca Raton, Florida, USA.

Kandeler, E., S. Palli, M. Stemmer, and M.H. Gerzabek. 1999. Tillage changes microbial biomass and enzymes activities in particle size fractions of a Haplic Chernozem. Soil Biology and Biochemistry 31:1253-1264.

Kizilkaya, R., T. Askin, B. Bayrakli, and M. Saglam. 2004. Microbiological characteristics of soils contaminated with heavy metals. European Journal of Soil Biology 40:95-102.

Kizilkaya, R., and B. Bayrakli. 2005. Effect of N enriched sewage sludge on soil enzyme activities. Applied Soil Ecology 30:192202. 
Kizilkaya, R., and I. Ekberli. 2008. Determination of the effects of hazelnut husk and tea waste treatments on urease enzyme activity and its kinetics in soil. Turkey Journal of Agricultural Forest 32:299-310.

Kizilkaya, R., I. Ekberli, and N. Kars. 2007. Tutun atigi ve bugday samani uygulanmis toprakta ureaz aktivitesi ve kinetigi. Ankara Universitiesi Ziraat Fakultesi Tarim Bilimleri Dergisi 13:186-194.

Klose, S., and M.A. Tabatabai. 2000. Urease activity of microbial biomass in soils as affected by cropping systems. Biology and Fertility of Soils 31:191-1999.

Kujur, M., S. Gartia, and A.K. Patel. 2012. Quantifying the contribution of different soil properties on enzyme activities in dry tropical ecosystems. Journal of Agricultural and Biological Science 7:763-772.

Kujur, M., and A.K. Patel. 2012. Quantifying the contribution of different soil properties on microbial biomass carbon, nitrogen and phosphorous in dry tropical ecosystem. International Journal of Environmental Sciences 2:2272-2284.

Ladd, J.N., and J.H.A. Butler. 1972. Short term assays of soil proteolytic enzymes activities using proteins and dipeptide derivatives as substrates. Soil Biology and Biochemistry 4:19-30.

Ludwig, J.A., and J.F. Reynolds. 1988. Statistical ecology: A primer in method and computing. 337 p. John Wiley and Sons, New York, USA.

Makoi, J., and P. Ndakidemi. 2008. Selected soil enzymes: Examples of their potential roles in the ecosystem. African Journal of Biotechnology 7:181-191.

Marx, M.C., E. Kandeler, M. Wood, N. Wermbter, and S.C. Jarvis. 2005. Exploring the enzymatic landscape: distribution and kinetics of hydrolytic enzymes in soil particle size fractions. Soil Biology and Biochemistry 37:35-48.

Masciandaro, G., B. Ceccanti, and V. Ronchi. 2000. Kinetic parameters of dehydrogenase in the assessment of the response of soil to vermicompost and inorganic fertilisers. Biology and Fertility of Soils 32:479-483.

Nannipieri, P., S. Grego, and B. Ceccanti. 1990. Ecological significance of the biological activity in soil. p. 293-355. In Bollag, J.M., and G. Stotzky (eds.) Soil biochemistry. Vol. 6. Marcel Dekker, New York, USA.

Nannipieri, P.B., E. Kandler, and P. Ruggiero. 2002. Enzyme activity and microbial and biochemical processes in soil. p. 1-33. In R.P. Dick et al. (eds.) Enzymes in the environment: Activity, ecology and applications. Marcel Dekker, New York, USA.

Nemergut, D., A. Townsend, and S. Sattin. 2008. The effect of chronic nitrogen fertilization on alpine tundra soil microbial communities: implication for carbon and nitrogen cycling. Environmental Microbiology 10:3093-3105.

Roberge, M.R. 1978. Methodology of soil enzyme measurement and extraction. p. 341-369. In R.G. Burns (ed.) Soil enzymes. Academic Press, London, UK.
Ross, D.J. 1983. Invertase and amylase activities as influenced by clay minerals, soil clay fractions and topsoil under grassland. Soil Biology and Biochemistry 15:287-293

Sardans, J., and J. Peñuelas. 2005. Drought decreases soil enzyme activity in a Mediterranean Quercus ilex L. forest. Soil Biology and Biochemistry 37:455-461.

Sardans, J., J. Peñuelas, and M. Estiarte. 2008. Changes in soil enzymes related to $\mathrm{C}$ and $\mathrm{N}$ cycle and in soil $\mathrm{C}$ and $\mathrm{N}$ content under prolonged warming and drought in a Mediterranean shrubland. Applied Soil Ecology 39:223-235.

Sarkar, S., S.R. Singh, and R.P. Singh. 2003. The effects of organic and inorganic fertilizers on soil physical conditions and the productivity of a rice-lentil cropping sequence in India. Indian Journal of Agricultural Sciences 140:419-425.

Saviozzi, L.M., R. Cardelli, and R. Riffaldi. 2001. A comparison of soil quality in adjacent cultivated, forest and native grass land soils. Plant Soil Science 233:251-259.

Singh, S., N. Ghosal, and K.P. Singh. 2007. Variations in microbial biomass and crop roots due to differing resource quality inputs in a tropical dry land agro-ecosystem. Soil Biology and Biochemistry 39:76-86.

Somogyi, M. 1952. Notes on sugar determination. Journal of Biology and Chemistry 195:12-22.

Stone, M.M., M.S. Weiss, C.L. Goodale, M.B.Adams, I.J. Fernandez, D.P. German, et al. 2011. Temperature sensitivity of soil enzyme kinetics under $\mathrm{N}$-fertilization in two temperate forests. Global Change Biology 8:1173-1184.

Subrahmanyam, G., G. Archana, and L.S. Chamyal. 2011. Soil microbial activity and its relation to soil indigenous properties in semi-arid alluvial and estuarine soils of Mahi river basin, Western India. International Journal of Soil Science 6:224-237.

Tabatabai, M.A. 1994. Soil enzymes. p. 775-833. In Weaver, R.W., et al. (eds.) Methods of soil analysis. Part 2. Microbiological and biochemical properties. Soil Science Society of America, Madison, Wisconsin, USA.

Tischer, S. 2005. Microbial biomass and enzyme activities on soil monitoring sites in Saxony-Anhalt, Germany. Archives of Agronomy and Soil Science 51:673 685.

Yang, Y.Z., S. Liu, D. Zheng, and S. Feng. 2006. Effects of cadmium, zinc and lead on soil enzyme activities. Journal of Environmental Science 18:1135-1141.

Zhang, Y.L., L.J. Chen, C.X. Sun, Z.J. Wu, Z.H. Chen, and G.H. Dong. 2010. Soil hydrolase activities and kinetic properties as affected by wheat cropping systems of northeastern china. Plant Soil and Environment 56(11):526-532.

Zhang, Y.L., Cc.X. Sun, L.J. Chen, and Z.H. Duan. 2009. Catalytic potential of soil hydrolases in northeast China under different soil moisture conditions. Revista de la Ciencia del Suelo y Nutrición Vegetal/Journal of Soil Science and Plant Nutrition 9:116-124. 